\title{
Technological capability accumulation in the 'maquila industry' in Mexico ${ }^{1}$
}

\author{
Gabriela Dutrénit* \\ Alexandre 0. Vera-Cruz**
}

\begin{abstract}
From the mid-1960s, 'maquila' plants were established in the Mexican Northern border. The Mexican model was based on foreign firms establishing their own assembly plants. Even though this model was less successful than that of East and South East Asian in terms of several techno-economic indicators, it has largely contributed to employment generation. However, as a result of internal learning process and changes in the global firms strategies, several 'maquilas' operating in Mexico have undergone important qualitative changes. During the 1990s there was a change in the nature of their productive and technological activities towards more complex products and more innovative technological activities. In contrast, other dimensions have evolved slowly, such as the engagement of Mexican suppliers in global supply chains. The aim of this paper is to discuss an analytical framework to help study the technological capability accumulation in the 'maquila' industry in Mexico. Based on that the paper seeks to examine levels of technological capability accumulation of three maquilas, and to bring to light some stylized facts of the accumulation process in this industry. The analytical framework proposed draws on the taxonomy of technological capabilities proposed by Bell \& Pavitt (1995) for the manufacturing industry in developing countries and its further adaptations and applications carried in Figueiredo (2001) and Ariffin \& Figueiredo $(2003,2004)$. This paper adapts it to the particularities of the 'maquila' industry in Mexico. The new taxonomy includes technical functions that are relevant to this industry and redefines activities that correspond to various levels of accumulation. This paper is based on a case study methodology. The cases are the business lines of three maquilas in Ciudad Juarez: Thomson Multimedia, Philips Corp. and Delphi Corp. Two business lines correspond to the consumer electronics industry and the third is specialized on electronic products for the auto-parts industry. The evidence was collected between April 2001 and October 2002 in Ciudad Juarez. The main source of information are interviews conducted on the personnel of different hierarchical positions within each 'maquila'.
\end{abstract}

Key words: Technological capabilities; maquila industry in Mexico.

\section{Introduction $^{2}$}

A group of countries of East and South East Asia achieved important successes in their processes of industrial and technological progress from the development of local suppliers of the manufacture industry. Based on processes of learning and accumulation of technological capability these local suppliers could advance rapidly from simple assembly activities in the 1960s and 1970s, toward product design in the late 1980s and finally to introducing their own brands in the international markets and carrying out $R \& D$ activities for new products in the 1990s. ${ }^{3}$

The industrial relocation process toward the northern border of Mexico began in the mid-1960s. On one side, the Mexican model was different to the East and South East Asian one, transnational firms established their

\footnotetext{
${ }^{1}$ This document was presented in the "7th International Conference on Technology Policy and Innovation", Monterrey, November 2002, and published in the proceedings of the conference edited by Gibson, D., M. Heitor and A. Ibarra-Yunez, Connecting People, Ideas, and Resources Across Communities, Greenwood Publishing Group: Connecticut, US.

* Master and Doctorate in Economic and Management of Technological Change and Department of Economics, Universidad Autónoma Metropolitana-Xochimilco. Email: dutrenit@ correo.xoc.uam.mx. Calzada del Hueso 1100, Col. Villa Quietud, Coyoacán, 04960, Mexico DF.

** Master and Doctorate in Economic and Management of Technological Change and Department of Economics, Universidad Autónoma Metropolitana- Xochimilco. Email: veracruz@ correo.xoc.uam.mx. Calzada del Hueso 1100, Col. Villa Quietud, Coyoacán, 04960, Mexico DF.

Artigo aceito para publicação em novembro de 2004 e aceito em março de 2005.

2 This paper is part of a research project "Technological learning and industrial upgrading. The generation of innovation capabilities in the maquila industry in México", COLEF/FLACSO/UAM (Proyecto CONACYT núm. 35947-s)

3 See for instance, Hobday (1995) and Kim (1997).
} 
own assembly plants in the northern border, which where denominated maquilas. ${ }^{4}$ On the other side, the evolution in Mexico has been less successful in terms of national industrial and technological development.

As consequence of the conditions and restrictions under which these plants where established, and of the poor attempt by the maquilas to form links with different Mexican industrial and governmental organizations, the stereotype that they were technologically poor establishments, were workers were submitted to repetitive and inhuman exploitation processes, was consolidated.

During the decade of the 1990s, the maquila industry consolidated its role as an employment generator in the manufacturing industry. Between 1990 and the year 2002, it created employments at an annual rate of over $10 \%$. In the 2002, the 1,087,487 workers employed in the 3,251 plants of the maquila industry represented $30 \%$ of the total personnel working in the whole manufacturing industry.

However, the evolution of the maquila industry was not limited to the growth of the number of establishments and employees. As a result of internal learning processes and changes in the strategies of global firms, various maquilas in Mexico have experienced important qualitative changes. Although there is no precise data to evaluate the depth and magnitude of such transformation, recent studies confirm that during the 1990s a change occurred in the nature of the productive and technological activities of a group of maquilas towards more complex products and more sophisticated technical activities. ${ }^{5}$ On the contrary, there are dimensions that have evolved more slowly, like the linking of national firms to their suppliers chains, particularly of components.

The aim of this paper is to present an analytical framework to help study the technological capability accumulation in the maquila industry in Mexico, based on that to analyze the levels of technological capability accumulation of three maquilas, and to bring to light some stylized facts of the accumulation process in this industry.

The analytical framework proposed draws on the taxonomy of technological capabilities proposed by Bell \& Pavitt (1995) for the manufacturing industry in developing countries, and its further adaptations and applications carried out in Figueiredo (2001) and Ariffin \& Figueiredo (2003, 2004). This paper adapts such framework to the particularities of the maquila industry in Mexico, in this sense the new taxonomy adds technical functions that are relevant to this industry and redefines activities that correspond to various levels of accumulation.

It is important to highlight that the framework focuses on intrafirm accumulation processes; it reveals the paths, processes and strategies of accumulation. However, it is less suitable to explain the links between these internal processes and the external context. Therefore, it is important to consider that the characteristics of the firms' capability paths depend on internal and external factors. Among the internal factors stand out the particularities of the firms foundation, their organizational and technological culture, and the business and technological strategies. These factors affects the building of organizational routines which shape the path of technological capability build-up. The most relevant external factors are associated with the economical and social environment in which firms operate, and with the characteristics of the local and national innovation systems.

The analysis of the accumulation processes of the maquilas in Mexico is placed in a national environment which has been characterized over decades by a macro economical instability and by the existence of an immature national innovation system, with a fragile structure of linkage among the different agents. Additionally, the maquilas were initially placed in localities in the northern border with little manufacturing tradition, a young educational system, inexistent R\&D centers, an immature local institutional structure, etc. In these localities it was impossible to talk about a local innovation system, a local productive system was barely being conformed. This affects both the accumulation of the maquilas and the development of local suppliers. This local environ-

4 From the mid-1960s, the Mexican government established a border industrialization program ("Programa de Industrialización Fronteriza") with the purpose of cutting down the high unemployment rates in the northern border of the country. This program had the purpose of attracting foreign investment, mainly from the US, to establish a 10 miles strip from the northern border. The plants created under this scheme were denominated maquilas. See Lowe \& Kenney (1999), Buitelaar (2000), Barajas et al (2002).

5 Carrillo \& Hualde (1997), Lara (2000), Dutrénit \& Vera-Cruz (2002). 
ment has evolved slowly since the maquilas have established very few external links. In fact, the local environment has been transformed into a binational regional environment, which increases the number of actors and opens spaces for further links. The locality of Ciudad Juarez is a representative case for the analysis of the maquila industry. It concentrates approximately $8 \%$ of the plants and $20 \%$ of the employment.

This paper is based on a case study methodology. The cases are the business lines of three maquilas in Ciudad Juarez: Thomson Multimedia, Philips Corp. and Delphi Corp. Two business lines correspond to the consumer electronics industry and the third is specialized on electronic products for the auto-parts industry. The evidence was collected between April 2001 and October 2002 in Ciudad Juarez. The main source of information were interviews conducted with managers, engineers, and technicians of different hierarchical positions within each maquila.

This paper is organized in five sections. Section 2 presents the analytical framework to assess the levels of technological capability accumulation in the maquila industry. Section 3 analyzes the trajectory of technological capability accumulation of the three cases being analyzed. Section 4 compares the trajectories of accumulation of the three maquilas. Finally, Section 5 presents some stylized facts of the technological capability accumulation processes in the maquila industry.

\section{A taxonomy of technological capabilities of the maquila industry}

Since the beginning of the 1980s, a group of authors have contributed to the gradual build-up of an analytical framework to help analyze the processes of accumulation of technological capabilities by firms in developing countries. ${ }^{7}$ The basic idea is that capabilities represent abilities to do things, and technological capabilities reflect the dominion of technological activities. Based on empirical research at firm level, this literature has elaborated taxonomies to help describe the gradual processes of accumulation, from a stage that reflects minimum levels of knowledge (needed for the routine operation) to the stage of advanced innovative capabilities. In this section we present a new version of the taxonomy of technological capabilities adapted to the particularities of the maquila industry in Mexico. An index of technological capabilities that measures the results of the accumulation processes is also presented.

The design of the taxonomy of technological capabilities for the maquila industry draws on the analytical framework proposed by Bell \& Pavitt (1995), which gathers up the advances of knowledge in this area, ${ }^{8}$ and on the adaptations carried out by Figueiredo (2001) and Ariffin \& Figueiredo (2004). The philosophy of the taxonomy is kept but, based on the evidence of the characteristics of the accumulation processes at the maquila industry, new technical functions are added and some of the activities corresponding to each level of accumulation are redefined.

The files group out the main technological capabilities according to the degree of innovativeness, including four levels of accumulation: a level of routine production technological capabilities, and three levels of innovative technological capabilities - basic, intermediate, and advanced. By columns, the taxonomy distinguishes the technical functions in which firms can develop technological capabilities. There are three groups of technical functions: (i) investment functions that refer to the creation of technical change and the administration of its implementation during large investment projects; (ii) production functions that refer to the generation and management of technical change in the processes, the production organization, and the products; and (iii) supporting functions that consist of the development of links and interactions necessary for innovative activity.

The taxonomy of technological capabilities in the maquila industry has the following particularities:

\footnotetext{
${ }^{7}$ Dahlman \& Westphal (1982), Katz (1984), Dahlman et al. (1987) and Lall (1992).

${ }^{8} \mathrm{~A}$ critical description of this taxonomy is presented in Dutrénit et al. (2003).
} 
1. It is defined for the activities of the maquilas in Mexico, so it shows the accumulation of technological capabilities in each plant, business line or the whole operations in Mexico, independent to the technological capabilities of the global firm.

2. Three technical supporting functions where defined: internal linkages, external linkages and equipment modification.

3. The difference between activities of internal and external linkages was due to the fact that they reflect two relevant aspects of the relationships of the maquilas: intrafirm links and links with the context. These dimensions have evolved differently.

4. Following Figueiredo (2001), the technical function of equipment modification was added since it is relevant in many firms in developing countries.

Table 1 presents the taxonomy of technological capabilities for the maquila industry. In each stage of accumulation of each technical function, the most characteristic activities of that level are listed. 


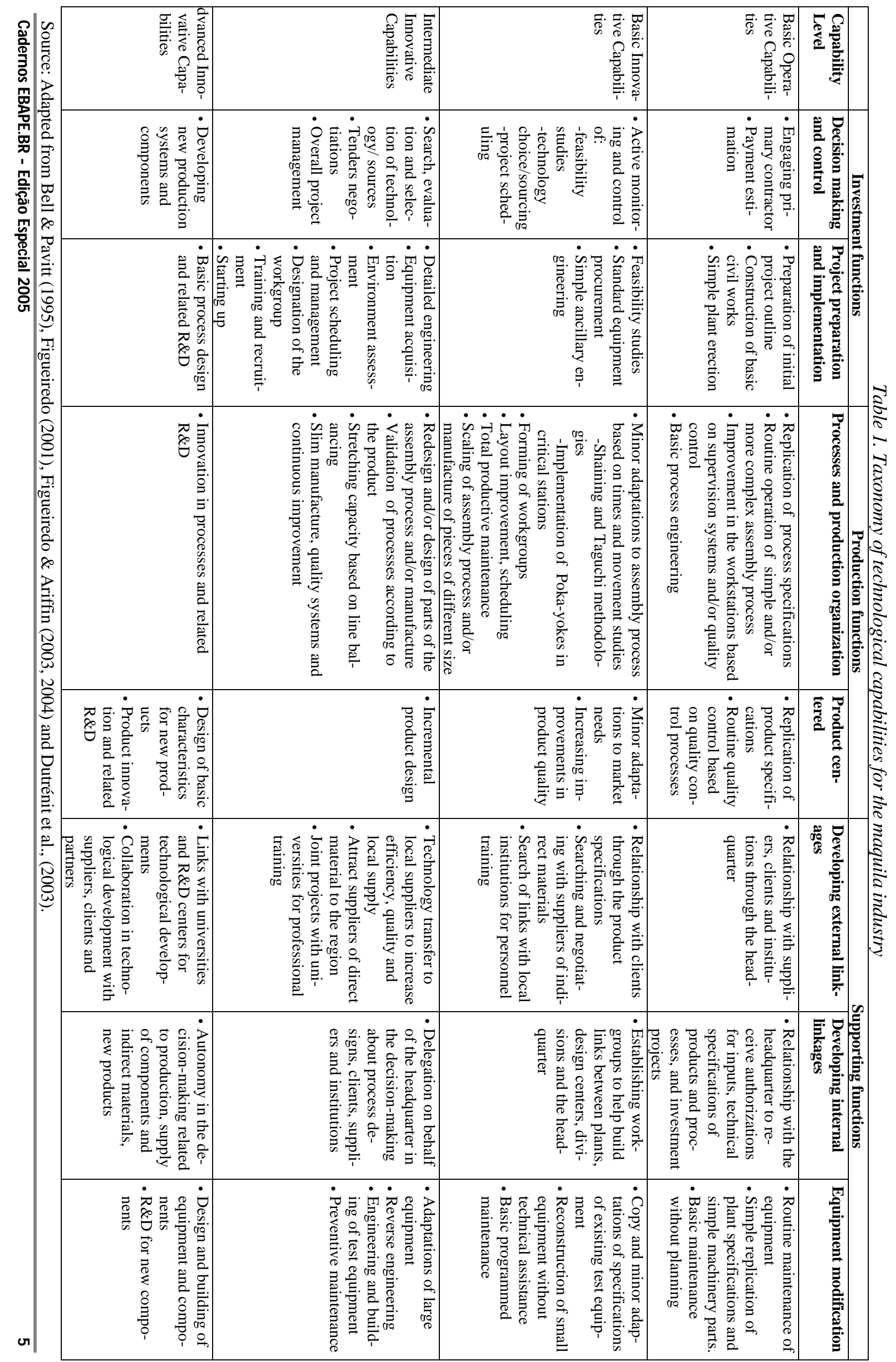




\section{Accumulation of technological capabilities in the maquila: empirical evidence}

Based on the framework described above, this section analyzes the trajectory of technological capability accumulation of three maquilas: Delphi Corp, Philips Corp, and Thomson Multimedia.

Since there exist differences in the technological capability accumulation processes per maquila's business line, in each case the most representative line of the process of technological capability accumulation in Mexico was chosen. In the case of Delphi we analyze the business line of sensors and actuators, as it is the line that has had the most advanced trajectory of technological capability accumulation in Mexico. In the case of Philips the business line of televisions is analyzed, with which it started activities in Mexico and which has worked like a seed for the rest of the activities in this country. In the case of Thomson we analyze the business of televisions, decoders and cable modem, where the 4 plants of Ciudad Juarez are integrated.

\section{Delphi Corp.: business line of sensors and actuators}

Delphi Corp is an autopart producer, specialized in mobile electronics and transportation components and systems technology, organized in 6 divisions. It is a firm oriented towards global integrated production that makes the decisions in different parts of the world. ${ }^{9}$ In 2001 it had approximately 192.000 employees and was operating in 42 countries. Its headquarters are located in Troy, Michigan, USA, and it has regional headquarters in Paris, Tokyo and Sao Paulo. ${ }^{10}$

Delphi was first established in Mexico as Delco Remy, under de maquila regime in 1979. In the year 2001 it had 72.000 employees, 50 productive plants in 14 states, 8 co-investments, 3 technology licenses and a Technical Center. In that year the production in Mexico represented 14.9\% of the total sales of the group.

The Mexican Technical Center (MTC) was established in Ciudad Juarez in 1995 with 714 employees who came from the plants in Mexico, other facilities of Delphi in the United States, and of the hiring of personnel in both Mexico and the United States. ${ }^{6}$ It is Delphi's biggest Component Engineering Center. Initially Delphi transferred to the MTC the engineering area of sensors and actuators. Gradually all the divisions have established areas of engineering and different laboratories in the MTC. In 2002 they had 2097 employees, of which approximately 1100 were engineers.

Most of the activities at the MTC are oriented to make developments for production. Only 3 of the 6 divisions operating at the MTC carry out product design activities. The most advanced division is Delphi Energy \& Chassis Systems, ${ }^{7}$ which carries out product design and advanced engineering. Inside this division, the largest capabilities in terms of R\&D are in the business of sensors and actuators.

The sensors and actuators are produced in 6 plants all over the world: 1in Ciudad Juarez, 2 in Chihuahua, 1 in Brazil, 1 in Portugal and 1 in China. It participates in the sensors and actuators market at international level with an $8.8 \%$ of the total. The engineering, design and development activities are located at the MTC. Here there is a group of advanced engineering of sensors and actuators with 6 doctors, 13 masters and 1 engineer. This group is in charge of developing the technology in the business line of sensors and actuators at world

\footnotetext{
${ }^{9}$ Delphi was a part of General Motors Company. In 1999 it separated and became an independent industrial group, Delphi Automotive System Corp. In 2002 it changed its name to Delphi Corp.

${ }^{10}$ Delphi concentrates its activities in North America (United States, Mexico and Canada), where $78 \%$ of the sales are generated. Europe represents the $18.4 \%$, South America the $1.5 \%$ and other areas, that include China, the $2.3 \%$. (DELPHI, 2002).

${ }^{6}$ The establishment of the MTC in Ciudad Juarez replied to different motives: (i) closeness with the plants to reduce the costs of line installation, response time and communications cost, (ii) restrictions to grow in the US by the 'Head Counter'; (iii) search to reduce operation costs, through reducing the cost of labor. (Interview at the MTC)

${ }^{7}$ Delphi-E\&C belongs to the Dynamic and propulsion business sector and has 14 business lines, sensors and actuators is one of them. It has two lines of products: sensors and actuators, these combine in a subsystem that allows to create intelligent modules of control. The modules combine sensors, actuators, electronics and software.
} 
level. The activities carried out at the MTC are the following: (i) part of the necessary applied research, (ii) all the advanced engineering, and (iii) the strategic and technological planning. ${ }^{8}$ To carry out development projects they interact with Delphi Technology Inc., which carries out part of the basic and applied research required, and with universities, mainly American, who provide basic research for the projects. ${ }^{9}$

From the analysis of the productive and technological history and of the structure of its links, three stages of evolution of Delphi's business line of sensors and actuators were identified. The definition of the beginning of a new stage is associated with a jump in the process of technological capability accumulation. ${ }^{10}$ Table 2 and 3 summarizes the main features of the accumulation at each stage and the accumulation levels in the technical functions according to the taxonomy of technological capabilities.

Table 2. Main features of the accumulation process of Delphi's business of sensors and actuators

\begin{tabular}{|c|c|c|}
\hline $\begin{array}{l}\text { Stage I. Simple assembly of } \\
\text { few components, 1978-88 }\end{array}$ & $\begin{array}{l}\text { Stage II. Complex assembly of } \\
\text { product families, 1989-94 }\end{array}$ & $\begin{array}{l}\text { Stage III. Product design, } \\
1995-2002\end{array}$ \\
\hline $\begin{array}{l}\text { - Simple assembly of compo- } \\
\text { nents and manufacture proc- } \\
\text { esses } \\
\text { - Few products } \\
\text { - 1979: first plant in Ciudad } \\
\text { Juarez (SEC-plant 35) } \\
\text { - 1986: second plant in Chi- } \\
\text { huahua-Chihuahua } \\
\text { - Basic engineering of proc- } \\
\text { esses } \\
\text { - System of conventional } \\
\text { drive manufacture. } \\
\text { - American managers } \\
\text { - Foreign inputs and other } \\
\text { components } \\
\text { - Minimum links with the lo- } \\
\text { cal and regional context }\end{array}$ & $\begin{array}{l}\text { - Complex assembly of compo- } \\
\text { nents and automatized manufac- } \\
\text { ture processes } \\
\text { - Various families of products } \\
\text { - 1990: third plant in Chihuahua- } \\
\text { Chihuahua } \\
\text { - Engineering of assembly proc- } \\
\text { esses } \\
\text { - System of synchronized manu- } \\
\text { facture with the client, multi- } \\
\text { functional work cells in U, } 1 \text { en- } \\
\text { gineer every } 2-3 \text { cell, sub plants } \\
\text { per families of products } \\
\text { - Statistical controls } \\
\text { - Development of Mexican man- } \\
\text { agers in sub plants } \\
\text { - Global suppliers } \\
\text { - Late } 1980 \text { 's: transfer of the in- } \\
\text { direct material buys area to the } \\
\text { MTC }\end{array}$ & $\begin{array}{l}\text { - Complex assembly of components } \\
\text { and subsystems, complex manufac- } \\
\text { ture processes and manufacture of } \\
\text { pieces for test and production equip- } \\
\text { ment } \\
\text { - Creation of a technical center } \\
\text { (MTC) } \\
\text { - From engineering of sensors and ac- } \\
\text { tuators toward advanced engineering } \\
\text { and R\&D activities } \\
\text { - Lean manufacturing } \\
\text { - Equipment improved through the } 6 \\
\text { sigma, documented quality control } \\
\text { (PIBAB) } \\
\text { - MTC makes some decisions locally } \\
\text { - } 90 \% \text { of direct material is bought in } \\
\text { US, } 10 \% \text { locally } \\
\text { - Various Mexican managers } \\
\text { - Global suppliers and some national } \\
\text { - Major links with the local and re- } \\
\text { gional context: agreements with re- } \\
\text { gional universities for professional } \\
\text { formation, incipient links with Mexi- } \\
\text { can research centers }\end{array}$ \\
\hline
\end{tabular}

Source: Derived from the empirical study.

\footnotetext{
${ }^{8}$ Additionally the planning of sales, marketing and investment are carried out. (MTC, 2000; and interviews at the MTC).

${ }^{9}$ One of the most important results of the innovative activity is the register of the intellectual property. In 2001 , the advanced engineering group obtained 88 record of investments, presented 55 applications of patents, was granted 15 patents, and realized 7 defensive publications and 3 industrial secrets. (Interview at the MTC).

${ }^{10}$ Arias (2002) presents a description of the three stages.
} 
Table 3. Accumulation levels of Delphi's business of sensors and actuators

\begin{tabular}{lccccccc}
\hline & $\begin{array}{c}\text { Technical Investment } \\
\text { functions }\end{array}$ & $\begin{array}{c}\text { Technical Invest- } \\
\text { ment functions }\end{array}$ & \multicolumn{2}{c}{ Technical supporting function } \\
\hline Stages & $\begin{array}{c}\text { Decision } \\
\text { making } \\
\text { and con- } \\
\text { trol }\end{array}$ & $\begin{array}{c}\text { Project } \\
\text { preparation } \\
\text { and imple- } \\
\text { ment. }\end{array}$ & $\begin{array}{c}\text { Processes } \\
\text { and pro- } \\
\text { duction } \\
\text { organiz. }\end{array}$ & $\begin{array}{c}\text { Product } \\
\text { centered }\end{array}$ & $\begin{array}{c}\text { Develop- } \\
\text { ing ex- } \\
\text { ternal } \\
\text { linkages }\end{array}$ & $\begin{array}{c}\text { Develop- } \\
\text { ing in- } \\
\text { ternal } \\
\text { linkages }\end{array}$ & $\begin{array}{c}\text { Equip- } \\
\text { ment } \\
\text { modifi- } \\
\text { cat. }\end{array}$ \\
\hline Stage I & Operatives & Operatives & $\begin{array}{c}\text { Opera- } \\
\text { tives }\end{array}$ & $\begin{array}{c}\text { Opera- } \\
\text { tives }\end{array}$ & $\begin{array}{c}\text { Opera- } \\
\text { tives }\end{array}$ & $\begin{array}{c}\text { Opera- } \\
\text { tives }\end{array}$ & $\begin{array}{c}\text { Opera- } \\
\text { tives }\end{array}$ \\
\hline Stage & $\begin{array}{c}\text { Basic In- } \\
\text { nov. }\end{array}$ & $\begin{array}{c}\text { Basic } \\
\text { Innov. }\end{array}$ & $\begin{array}{c}\text { Intermed. } \\
\text { Innov. }\end{array}$ & $\begin{array}{c}\text { Basic In- } \\
\text { nov. }\end{array}$ & $\begin{array}{c}\text { Basic In- } \\
\text { nov. }\end{array}$ & $\begin{array}{c}\text { Opera- } \\
\text { tives }\end{array}$ & $\begin{array}{c}\text { Basic In- } \\
\text { nov. }\end{array}$ \\
\hline Stage & $\begin{array}{c}\text { Intermed. } \\
\text { Innov. }\end{array}$ & $\begin{array}{c}\text { Intermed. } \\
\text { Innov. }\end{array}$ & $\begin{array}{c}\text { Advanced } \\
\text { III }\end{array}$ & $\begin{array}{c}\text { Advanced } \\
\text { Innov. }\end{array}$ & $\begin{array}{c}\text { Advanced } \\
\text { Innov. }\end{array}$ & $\begin{array}{c}\text { Intermed. } \\
\text { Innov. }\end{array}$ & $\begin{array}{c}\text { Intermed. } \\
\text { Innov. }\end{array}$ \\
\hline
\end{tabular}

Source: Derived from the empirical study.

\section{Philips Corp: business line of televisions}

Royal Philips Electronics was founded in 1891 to produce incandescent lamps and other electric products. Its headquarter is located in Amsterdam, Holland. It has seven business sectors: Lighting, Consumer electronics, Electro domestic equipment and personal care, Medical systems, Components, Semiconductors, and Miscellaneous. It is oriented towards globally integrated production. In 2001 it had approximately 229.000 employees and operated in over 60 countries. It has regional management offices in Europe; Asia, Middle East and Africa; Latin America (Brazil); and North America.

Philips began its operations in Mexico in 1939 as a wholesaler of imported products from Europe with the name Philips Mexicana, S.A. de C.V. In 1973 the first plant of Royal Philips Electronics was established in Ciudad Juarez under the regime of maquila. In 2002 Philips Mexico had a total of 15 plants all over the country, of which 12 were maquila plants of different products, and counted with 11.500 employees. At present Philips Mexico belongs to the Latin American region with headquarters in Sao Paulo, Brazil.

The business of televisions belongs to the sector of Consumer Electronics. Philips assembles and manufactures televisions in different parts of the world. The activities of engineering, design and development of this line are located in Singapore, Bruges and Knoxville.

As in the previous case, three stages of evolution of the business of televisions in Philips were identified. ${ }^{11}$ Table 4 and 5 summarizes the main features of the accumulation in each stage.

\footnotetext{
${ }^{11}$ Urióstegui (2002) presents a description of the three stages.
} 
Table 4. Main features of the accumulation process of Philips's business of televisions

\begin{tabular}{|c|c|c|}
\hline $\begin{array}{l}\text { Stage I. Simple assembly of } \\
\text { components (1973-83) }\end{array}$ & $\begin{array}{c}\text { Stage II. Assembly of chassis } \\
(\mathbf{1 9 8 4 - 8 6 )}\end{array}$ & $\begin{array}{c}\text { Stage III. Assembly of televi- } \\
\text { sions (1987-2002) }\end{array}$ \\
\hline $\begin{array}{l}\text { - Simple assembly of compo- } \\
\text { nents and manufacture proc- } \\
\text { esses } \\
\text { - Few products } \\
\text { - 1973: first plant (SESA) } \\
\text { - 1974: first line of assembly of } \\
\text { chassis } \\
\text { - Creation of several plants of } \\
\text { sub assembly and components } \\
\text { - Basic engineering of processes } \\
\text { - 1973: machining workshop at } \\
\text { the plant SESA } \\
\text { - Foreign managers } \\
\text { - Minimum links with the local }\end{array}$ & $\begin{array}{l}\text { - Assembly of more complex } \\
\text { products and manufacture proc- } \\
\text { esses } \\
\text { - Creation of several plants of } \\
\text { sub assembly and components } \\
\text { - Engineering of assembly proc- } \\
\text { esses } \\
\text { - Design engineering: original } \\
\text { proposal of the manufacturing } \\
\text { process for the televisions } \\
\text { - Plant engineering: develop- } \\
\text { ment of capabilities in large in- } \\
\text { vestment projects } \\
\text { - Reconstruction of small } \\
\text { equipment } \\
\text { - Some few Mexican managers } \\
\text { - Components bought from } \\
\text { Knoxville (US) with global } \\
\text { suppliers } \\
\text { - 1980-97: "Program for the } \\
\text { Development of Local Suppli- } \\
\text { ers" of indirect material, inte- } \\
\text { gration of a limited group of lo- } \\
\text { cal suppliers }\end{array}$ & $\begin{array}{l}\text { - Assembly of televisions and } \\
\text { complex manufacture processes } \\
\text { - 1987: plant } 5 \text { for final assem- } \\
\text { bly of televisions (previously } \\
\text { SESA) } \\
\text { - 2000: plant } 10 \text { for assembly of } \\
\text { chassis for all kinds of televi- } \\
\text { sions } \\
\text { - 2001: line of televisions PTV } \\
\text { - Evolution of the capabilities in } \\
\text { equipment modification: tech- } \\
\text { nical support for all the plants } \\
\text { in Ciudad Juarez (1991), new } \\
\text { business line (1997) and new } \\
\text { plant (1998) }{ }^{12} \\
\text { - Various Mexican managers } \\
\text { - Global suppliers and some na- } \\
\text { tional suppliers } \\
\text { - Major links with the local and } \\
\text { regional context: creation of a } \\
\text { public-private training center - } \\
\text { CENALTEC- oriented to the } \\
\text { training of technicians in ma- } \\
\text { chine-tools }\end{array}$ \\
\hline
\end{tabular}

Source: Derived from the empirical study.

Table 5. Accumulation levels in each stage of accumulation of Philips's business of televisions

\begin{tabular}{|c|c|c|c|c|c|c|c|}
\hline & \multicolumn{2}{|c|}{$\begin{array}{c}\text { Technical Investment } \\
\text { functions }\end{array}$} & \multicolumn{2}{|c|}{$\begin{array}{l}\text { Technical Invest- } \\
\text { ment functions }\end{array}$} & \multicolumn{3}{|c|}{ Technical supporting function } \\
\hline Stages & $\begin{array}{l}\text { Decision } \\
\text { making } \\
\text { and con- } \\
\text { trol }\end{array}$ & $\begin{array}{c}\text { Project } \\
\text { preparation } \\
\text { and imple- } \\
\text { ment. }\end{array}$ & $\begin{array}{l}\text { Processes } \\
\text { and pro- } \\
\text { duction } \\
\text { organiz. }\end{array}$ & $\begin{array}{l}\text { Product } \\
\text { centered }\end{array}$ & $\begin{array}{c}\text { Develop- } \\
\text { ing ex- } \\
\text { ternal } \\
\text { linkages }\end{array}$ & $\begin{array}{l}\text { Develop- } \\
\text { ing in- } \\
\text { ternal } \\
\text { linkages }\end{array}$ & $\begin{array}{l}\text { Equip- } \\
\text { ment } \\
\text { modifi- } \\
\text { cat. }\end{array}$ \\
\hline Stage I & Operatives & Operatives & $\begin{array}{l}\text { Opera- } \\
\text { tives }\end{array}$ & $\begin{array}{l}\text { Opera- } \\
\text { tives }\end{array}$ & $\begin{array}{l}\text { Opera- } \\
\text { tives }\end{array}$ & $\begin{array}{l}\text { Opera- } \\
\text { tives }\end{array}$ & $\begin{array}{l}\text { Opera- } \\
\text { tives }\end{array}$ \\
\hline $\begin{array}{l}\text { Stage } \\
\text { II }\end{array}$ & $\begin{array}{l}\text { Basic } \\
\text { Innov. }\end{array}$ & $\begin{array}{l}\text { Basic } \\
\text { Innov. }\end{array}$ & $\begin{array}{l}\text { Basic In- } \\
\text { nov. }\end{array}$ & $\begin{array}{l}\text { Opera- } \\
\text { tives }\end{array}$ & $\begin{array}{l}\text { Opera- } \\
\text { tives }\end{array}$ & $\begin{array}{l}\text { Opera- } \\
\text { tives }\end{array}$ & $\begin{array}{l}\text { Basic In- } \\
\text { nov. }\end{array}$ \\
\hline $\begin{array}{l}\text { Stage } \\
\text { III }\end{array}$ & $\begin{array}{l}\text { Intermed. } \\
\text { Innov. }\end{array}$ & $\begin{array}{l}\text { Intermed. } \\
\text { Innov. }\end{array}$ & $\begin{array}{l}\text { Intermed. } \\
\text { Innov. }\end{array}$ & $\begin{array}{l}\text { Basic In- } \\
\text { nov. }\end{array}$ & $\begin{array}{l}\text { Basic In- } \\
\text { nov. }\end{array}$ & $\begin{array}{l}\text { Basic In- } \\
\text { nov. }\end{array}$ & $\begin{array}{l}\text { Intermed. } \\
\text { Innov. }\end{array}$ \\
\hline
\end{tabular}

Source: Derived from the empirical study.

\footnotetext{
${ }^{12}$ In 2001 Philips decided to sell Enabling Technologies Group (where this business was located) because it was not considered a central business. This led to reorient the activity of this plant toward the business of plastic moulds for injection, stopping the process of accumulation in equipment modification. (Interview at Philips)
} 


\section{Thomson Multimedia: the business of televisions, digital decoders and cable modem}

Thomson Multimedia is a firm of consumer electronics products whose headquarter is located in Bologna, France. It was founded in 1879 under the name Compagnie Francaise Thomson-Houston. It has five business sectors, the sector of Consumer Products represents the $62.7 \%$ of its sales. It manages three large brands: Thomson, RCA and Technicolor. It is oriented toward global integrated production. In 2001 it had approximately 73.000 employees, operated in over 30 countries and has 31 production plants. In 2001 Asia represented $33 \%$ of the sales, America 40\% (18\% corresponding to the US) and Europe 27\%. America includes the United States, Canada, Mexico and Brazil. ${ }^{13}$

The history of the beginning of Thomson's operations in Mexico is linked with RCA. In 1952, RCA established a plant of assembly of radios, kinescopes and cannons for television in Mexico City. In 1969 an assembly plant is established in Ciudad Juarez (Chihuahua) to carry out assembly processes of electronic components for radios and televisions produced in the US under the regime of maquila. At present, Thomson Multimedia's activities in Ciudad Juarez correspond to Thomson Consumer Electronics, it has four plants that assemble components and final products and one plant for the rebuilding of products of the RCA brand. From 1998 to 2002 it had a Support Center. Additionally Thomson has a plant in Torreón (Coahuila) and a plant in Mexicali (Baja California). Like in the previous two cases, three stages of evolution of the business of televisions, decoders and cable MODEM were recognized. ${ }^{14}$ Table 6 and 7 below summarizes the main features of accumulation in each stage.

\footnotetext{
${ }^{13}$ www.thomson-multimedia.com

${ }^{14}$ Sampedro (2003) presents a description of the three stages.
} 
Table 6. Main features of the accumulation process of Thomson's business of televisions, decoders and cable MODEM

\begin{tabular}{|c|c|c|}
\hline $\begin{array}{l}\text { Stage I. Simple assembly of } \\
\text { components }(1969-80)\end{array}$ & $\begin{array}{l}\text { Stage II. Complex assembly and } \\
\text { equipment modification (1981-92) }\end{array}$ & $\begin{array}{l}\text { Stage III. Final assembly and } \\
\text { design (1993-2002) }\end{array}$ \\
\hline $\begin{array}{l}\text { - Simple assembly of compo- } \\
\text { nents and manufacture proc- } \\
\text { esses } \\
\text { - 1969: plant RCA. } \\
\text { - Basic engineering of proc- } \\
\text { esses } \\
\text { - Test technology was intro- } \\
\text { duced, ATE (automatic test } \\
\text { equipment) } \\
\text { - Development of capabilities } \\
\text { to modify test and assembly } \\
\text { equipment } \\
\text { - American managers } \\
\text { - Minimum links wit the re- } \\
\text { gional context }\end{array}$ & $\begin{array}{l}\text { - Assembly of more complex prod- } \\
\text { ucts and manufacture processes } \\
\text { - Engineering of manufacture } \\
\text { - Redesign of processes and assem- } \\
\text { bly lines } \\
\text { - Increasing improvements to the } \\
\text { basic product design according to } \\
\text { the production needs and clients' } \\
\text { requirements } \\
\text { - } 1981 \text { : the small, more sophisti- } \\
\text { cated manuals and the semiauto- } \\
\text { matic ATES were built in Ciudad } \\
\text { Juárez } \\
\text { - Plant engineering: development of } \\
\text { capabilities in large investment pro- } \\
\text { jects } \\
\text { - Incorporation of Mexican manag- } \\
\text { ers } \\
\text { - Global suppliers }\end{array}$ & $\begin{array}{l}\text { - Final assembly of televisions, } \\
\text { decoders and cable MODEM, and } \\
\text { complex manufacture processes } \\
\text { - 1993: plant TTM to begin the } \\
\text { final assembly of televisions, de- } \\
\text { coders and cable Modem } \\
\text { - 1998: plant MASA to increase } \\
\text { the assembly of digital televisions } \\
\text { - Division of work between the } \\
\text { three plants but they all have } \\
\text { flexibility to change their assem- } \\
\text { bly lines } \\
\text { - 1996-98: a support center is cre- } \\
\text { ated to turn it into a fourth global } \\
\text { design center for basic televisions } \\
\text { of } 19 \text { " and } 27 \text { ', in } 2002 \text { the } \\
\text { global strategy changes, the sup- } \\
\text { port center is closed and some ac- } \\
\text { tivities are decentralized to the } \\
\text { plants } \\
\text { - 2000 a team of software design } \\
\text { for decoders GLA is created and } \\
\text { located in a plant } \\
\text { - Design and manufacture of test } \\
\text { equipment, design of tools to ad- } \\
\text { just processes, and export of these } \\
\text { equipment to Brazil } \\
\text { - Global suppliers and some na- } \\
\text { tional suppliers of machining } \\
\text { pieces, packaging and simple } \\
\text { welding. } \\
\text { - Various Mexican managers } \\
\text { - Major links with the local and } \\
\text { regional contexts: professional } \\
\text { formation and training }\end{array}$ \\
\hline
\end{tabular}

Source: Derived from the empirical study.

\footnotetext{
${ }^{15}$ In 2002 there was a change in the strategy of the global firm, it decided to turn Thomson into a global organization, thus, it was no longer profitable to have another engineering group in design development in Ciudad Juarez.
} 
Table 7. Accumulation levels in each stage of accumulation of Thomson's business of televisions, decoders and cable MODEM

\begin{tabular}{lccccccc}
\hline Stages & $\begin{array}{c}\text { Technical Investment } \\
\text { functions }\end{array}$ & $\begin{array}{c}\text { Technical Investment } \\
\text { functions }\end{array}$ & \multicolumn{3}{c}{ Technical supporting function } \\
& $\begin{array}{c}\text { Decision } \\
\text { making } \\
\text { and con- } \\
\text { trol }\end{array}$ & $\begin{array}{c}\text { Project } \\
\text { preparation } \\
\text { and imple- } \\
\text { ment. }\end{array}$ & $\begin{array}{c}\text { Processes and } \\
\text { production } \\
\text { organization }\end{array}$ & $\begin{array}{c}\text { Product } \\
\text { centered }\end{array}$ & $\begin{array}{c}\text { Develop- } \\
\text { ing ex- } \\
\text { ternal } \\
\text { linkages }\end{array}$ & $\begin{array}{c}\text { Develop- } \\
\text { ing in- } \\
\text { ternal } \\
\text { linkages }\end{array}$ & $\begin{array}{c}\text { Equipment } \\
\text { modifica- } \\
\text { tion. }\end{array}$ \\
\hline Stage I I & Operatives & Operatives & Operatives & $\begin{array}{c}\text { Opera- } \\
\text { tives }\end{array}$ & $\begin{array}{c}\text { Opera- } \\
\text { tives }\end{array}$ & $\begin{array}{c}\text { Opera- } \\
\text { tives }\end{array}$ & Operatives \\
\hline Stage & Basic In- & Basic & Intermed. In- & Basic In- \\
nov. & $\begin{array}{c}\text { Basic In- } \\
\text { nov. }\end{array}$ & $\begin{array}{c}\text { Basic In- } \\
\text { nov. }\end{array}$ & $\begin{array}{c}\text { Intermed. In- } \\
\text { nov. }\end{array}$ \\
\hline nov. & Innov. & nov. & noved \\
\hline $\begin{array}{l}\text { Stage } \\
\text { III }\end{array}$ & $\begin{array}{c}\text { Intermed. } \\
\text { Innov. }\end{array}$ & $\begin{array}{c}\text { Intermed. } \\
\text { Innov. }\end{array}$ & $\begin{array}{c}\text { Intermed. In- } \\
\text { nov. }\end{array}$ & $\begin{array}{c}\text { Intermed. } \\
\text { Innov. }\end{array}$ & $\begin{array}{c}\text { Basic In- } \\
\text { nov. }\end{array}$ & $\begin{array}{c}\text { Basic In- } \\
\text { nov. }\end{array}$ & $\begin{array}{c}\text { Advanced } \\
\text { Innov. }\end{array}$ \\
\hline
\end{tabular}

Source: Derived from the empirical study.

\section{Comparison of the accumulation of capability levels in the case- study maquilas}

The analysis of the technological capability accumulation trajectories of Delphi, Philips and Thomson put forward some common features as well as certain differences. In this section the trajectories of technological capability accumulation of the three maquilas are compared and the similarities and differences extracted.

Tables 3, 5 and 7 present the level of technological capability accumulation of Delphi, Philips and Thomson in Mexico. In each case three stages of accumulation were identified, these were defined in function of jumps observed in the evolution. The first stage starts in the first years in Mexico, the second is a stage of transition, and the third reflects the present profile.

In the three cases there was a gradual accumulation of technological capabilities, the three maquilas evolved fruit of changing from having basic operative technological capabilities to having each time more innovative technological capabilities. In the first stage they all acquired basic operative technological capabilities, necessary for efficient production, and in the second predominates the development of basic innovative technological capabilities. In the present stage Philips and Thomson advanced toward intermediate innovative technological capabilities while Delphi obtained advanced innovative technological capabilities in most of its technical functions.

Differences in the level of accumulation can be observed in each stage of accumulation. In the third stage Delphi reached a highest level of accumulation in most of its technical functions because it transferred the product design of the sensors and actuators business line to Mexico, and the group of advanced engineering at the MTC began to carry out also R\&D activities. Philips presents the lowest level of accumulation, in fact Philips' present stage corresponds to the stage 2 of Delphi and Thomson, this because Philips did not advance toward product design and also desaccumulated in the equipment modification activities.

The differences observed in the evolution are associated both with the specificities of the process of internal accumulation in each maquila, and with their corporate strategy. In this sense, the transfer of the product design activities of Delphi's sensors and actuators line to Mexico is the result of a corporate decision based on the accumulation of local technological capabilities in this business line. The slow evolution of Thomson toward design activities is more associated with a corporate decision to concentrate the design in the three existing global centers, than with a scarce internal accumulation of technological capabilities. 
Aside from the differences in the specific years in which the jumps in the accumulation processes took place, it can be established that the stages are as follows: (i) First stage: early 1970s - early 1980s; (ii) Second stage: early 1980s - early 1990s; and (iii) Third stage: early 1990s - 2002.

Although there has been an advance in the accumulation of innovative technological capabilities locally, the three cases show that the evolution has been slow, particularly in relation to East and Southeast Asia. It took Delphi 19 years to advance toward product design, the first plant was established in 1979 and the group of advanced engineering was not established until 1997. Thomson took 31 years to advance toward product and software design, since the creation of the plant of RCA in 1969 until the constitution of the first product design group in 2000; these activities are still incipient. Philips has accumulated engineering capabilities, but has not accumulated neither design capabilities nor R\&D locally.

The accumulation was gradual, but the technical functions evolved differently, in fact in some functions the accumulation was faster than in others, thus the level of innovativeness reached was different. As shown in Table 8 , there are certain similarities in the characteristics of the accumulation per technical function.

Tabla 8. Comparison of the technological capabilities accumulation in the three maquilas

\begin{tabular}{|c|c|c|c|c|c|c|c|}
\hline \multirow[b]{2}{*}{ Maquila } & \multicolumn{2}{|c|}{$\begin{array}{c}\text { Technical Investment } \\
\text { functions }\end{array}$} & \multicolumn{2}{|c|}{$\begin{array}{c}\text { Technical Investment } \\
\text { functions }\end{array}$} & \multicolumn{3}{|c|}{ Technical supporting function } \\
\hline & $\begin{array}{l}\text { Decision } \\
\text { making } \\
\text { and con- } \\
\text { trol }\end{array}$ & $\begin{array}{c}\text { Project } \\
\text { preparation } \\
\text { and imple- } \\
\text { ment. }\end{array}$ & $\begin{array}{l}\text { Processes } \\
\text { and pro- } \\
\text { duction or- } \\
\text { ganization }\end{array}$ & $\begin{array}{l}\text { Product } \\
\text { centered }\end{array}$ & $\begin{array}{c}\text { Develop- } \\
\text { ing ex- } \\
\text { ternal } \\
\text { linkages }\end{array}$ & $\begin{array}{l}\text { Develop- } \\
\text { ing in- } \\
\text { ternal } \\
\text { linkages }\end{array}$ & $\begin{array}{l}\text { Equipment } \\
\text { modifica- } \\
\text { tion }\end{array}$ \\
\hline $\begin{array}{l}\text { Delphi } \\
1995- \\
2002\end{array}$ & $\begin{array}{l}\text { Intermed. } \\
\text { Innov. }\end{array}$ & $\begin{array}{l}\text { Intermed. } \\
\text { Innov. }\end{array}$ & $\begin{array}{l}\text { Advanced } \\
\text { Innov. }\end{array}$ & $\begin{array}{l}\text { Ad- } \\
\text { vanced } \\
\text { Innov. }\end{array}$ & $\begin{array}{l}\text { Advanced } \\
\text { Innov. }\end{array}$ & $\begin{array}{l}\text { Intermed. } \\
\text { Innov. }\end{array}$ & $\begin{array}{l}\text { Intermed. } \\
\text { Innov. }\end{array}$ \\
\hline $\begin{array}{l}\text { Philips } \\
1987- \\
2002\end{array}$ & $\begin{array}{l}\text { Intermed. } \\
\text { Innov. }\end{array}$ & $\begin{array}{l}\text { Intermed. } \\
\text { Innov. }\end{array}$ & $\begin{array}{l}\text { Intermed. } \\
\text { Innov. }\end{array}$ & $\begin{array}{l}\text { Basic } \\
\text { Innov. }\end{array}$ & $\begin{array}{l}\text { Basic } \\
\text { Innov. }\end{array}$ & $\begin{array}{l}\text { Basic } \\
\text { Innov. }\end{array}$ & $\begin{array}{l}\text { Intermed. } \\
\text { Innov. }\end{array}$ \\
\hline $\begin{array}{l}\text { Thom- } \\
\text { son } \\
1993- \\
2002\end{array}$ & $\begin{array}{l}\text { Intermed. } \\
\text { Innov. }\end{array}$ & $\begin{array}{l}\text { Intermed. } \\
\text { Innov. }\end{array}$ & $\begin{array}{l}\text { Intermed. } \\
\text { Innov. }\end{array}$ & $\begin{array}{l}\text { Inter- } \\
\text { med. In- } \\
\text { nov. }\end{array}$ & $\begin{array}{l}\text { Basic } \\
\text { Innov. }\end{array}$ & $\begin{array}{l}\text { Basic } \\
\text { Innov. }\end{array}$ & $\begin{array}{l}\text { Advanced } \\
\text { Innov. }\end{array}$ \\
\hline
\end{tabular}

Source: Derived from the empirical study.

The technical functions where the accumulation was faster in the three maquilas were: (i) Centered in processes and production organization, (ii) Equipment modification, and (iii) Decision making and control, and Project preparation and implementation. In the three maquilas these functions reached intermediate innovative technological capabilities in the second stage of accumulation. These technical functions are based mainly on accumulation processes at plant level, needed to assure efficient assembly processes given the local specificities. In contrast, the functions were there was less accumulation, or the accumulation was slower were: (i) Product centered, (ii) Internal linkages, and (iii) External linkages. These technical functions depend on decisions that transcend the plants and are made at firm level. In this sense, the activities of product design and the buys of key components are made globally. Also, as plant level is transcended, other kind of interactions are established between different units of the firms.

Important differences can be observed in the accumulation of the three maquilas in the function centered on the product. Delphi and Thomson progressed toward intermediate or advanced innovative technological capabilities in the third stage, this because Delphi began to carry out product design activities, and Thomson software design activities. The slow evolution of the technical function of external linkages reflects the existence of few local links for innovation, the stronger links are for professional formation and training. Delphi's higher accumulation shows that, although it is a global firm, it is difficult to prevent a disintegration of the basic activities 
to ensure the constant renovation of the competitive advantages. In addition to that, carrying out activities of design and R\&D raises the need of some links with local, regional and international institutions for innovation. It is important to point out that external links are with the region, defined bi-nationally.

Finally, Delphi accumulated more in all its technical functions, which is related to the transfer of a global line, and not just a plant, to Ciudad Juarez. Thus, a more important part of the decision center is in Ciudad Juarez.

\section{Final remarks}

The analysis carried out in this study allows us to identify some common features in the process of technological capability accumulation in these three case-study maquilas in Mexico. These common features in the accumulation processes suggest the existence of some stylized facts.

- The accumulation process differs in each business line, given the specificities of the process of internal accumulation and the corporate strategy of the global firm.

- As plants learn, they spread in technical activities with a high degree of innovativeness and develop innovative technological capabilities.

- The learning processes in the plants lead to the accumulation of technological capabilities locally in order to shorten the distance between the production and technology functions. This generates pressure on the headquarters to acknowledge the technological capabilities accumulated and allow them to develop technical activities of higher innovativeness.

- Local accumulation is a necessary condition, although not sufficient, for global firms to transfer technical activities to Mexico; the global logic governs over the internal accumulation of technological capabilities.

- The maquilas in Mexico are not firms, initially they were simply plants, so that they learnt and accumulated in the technical functions related with plants. Thus there has been a faster process of accumulation in the technical function centered in processes, in the modification of test equipment, and in the investment functions in large projects.

- The headquarters maintain the power of decision on the technical functions centered on the products (design and $R \& D$ ), internal linkages, and in the links with the suppliers of components that correspond to the function of external linkages.

- Some maquilas evolved in the sense of attracting global business lines, which allowed accumulating in technical functions related with product innovation, internal linkages, and external linkages.

- The development of managerial abilities among Mexicans has been slow because of the lack of opportunities to assume positions of high level locally. As they assume positions of higher responsibility, they look to strengthen the development of more innovative technological activities and integrate Mexican suppliers.

- The maquilas have followed an evolution related with the pressures of international competition. Beyond the efforts to develop national suppliers, the logic of businesses is radically different, moreover the gap between the types of firms has accentuated.

- The limited external links are associated with three factors: (i) the decision center above key factors outside is the locality, (ii) the profile of the activities at the plant - more productive than technical - that has demanded mostly links for training, and (iii) the weaknesses of the local production and innovation system, which do not have the capacity to respond to links for innovation.

- In general, the fragility of the production and innovation system, and of the social weave has not facilitated the linking processes of the local agents with the maquila. 


\section{References}

AMSDEN, A. H. Asia's next giant: South Korea and late industrialization. New York: Oxford University Press, 1989.

ARIAS, A. Capacidades tecnológicas en I+D y diseño en la industria maquiladora mexicana: el caso de Delphi Corp. Working paper (Doctorado en Ciencias Sociales) - UAM - X, 2002.

ARIFFIN, N.; FIGUEIREDO, P. Internacionalização de competências tecnológicas. Implicações para estratégias governamentais e empresariais de inovação e competitividade da indústria eletrônica no Brasil. Rio de Janeiro : Editora Fundação Getulio Vargas, 2003.

ARIFFIN, N.; FIGUEIREDO, P. Internationalisation of innovative capabilities: counter-evidence from the electronics industry in Malaysia and Brazil. Oxford Development Studies, v. 32, n. 4, 2004, pp. 559-583.

BARAJAS et al. Industria maquiladora en México: perspectivas del aprendizaje tecnológico-organizacional and escalamiento industrial. Monografía n.3 (proyecto Aprendizaje Tecnológico y Escalamiento Industrial: Generación de Capacidades de Innovación en la Industria Maquiladora de México) - Colef/Flacso/UAM, 2002.

BELL, M.; PAVITT, K. Accumulation and industrial growth: contrast between developed and developing countries. Industrial and Corporate Change, v.2, n.2, 1993.

The development of technological capabilities. In: HAQUE, I. U. (Ed.). Trade, technology and international competitiveness. Washington: The World Bank, 1995. p.69-101.

BUITELAAR, R. Maquila, economic reform and corporate strategies. World Development, v.28, n.9, p.1627-1642, 2000.

CARRILO, J.; HUALDE, A. Maquiladoras de tercera generación. El caso de Delphi-General Motors. Comercio Exterior, v.47, n.9, p.747-758, 1997.

DAHLM AN, C.; ROSS-LARSEN, B.; WESTPHAL, L. E. Managing technological development. World Development, v.15, n.6, p.759-75, 1987.

; WESTPHAL, L. E. Technological effort in industrial development. An interpretative survey of recent research. In: STEWART, F.;

JAMES, J. (Ed.). The economics of new technology in developing countries. London: Frances Pinter, 1982. p.105-137.

DELPHI CORP. Annual report. Michigan, [entre 1993 e 2003]

DUTRÉNIT, G. et al. Marco analítico para el análisis de los procesos de acumulación de capacidades tecnológicas. Working paper (proyecto Aprendizaje Tecnológico y Escalamiento Industrial: Generación de capacidades de innovación en la industria maquiladora de México) - Colef/Flacso/UAM, 2002.

; VERA-CRUZ, A. O. Rompiendo paradigmas: acumulación de capacidades tecnológicas en la maquila de exportación. Innovación y Competitividad, año II, n.6, p.11-15, 2002.

; _____; ALVAREZ, J.; RODRÍGUEZ, L. Estrategia tecnológica y demanda de investigación básica. El caso de dos empresas en México. El Trimestre Económico, v.LXX-4, n.280, p 835-877, 2003.

; ARIAS, A. Diferencias en los perfiles de acumulación de capacidades tecnológicas en tres empresas mexicanas. El Trimestre Económico, v.LXX-1, n.277, p.109-165, 2003.

FIGUEIREDO, P. N. Technological learning and competitive performance. Cheltenham: Edward Elgar, 2001.

GEREFFI, G. The "old" and "new" maquiladora industry in Mexico: what is their contribution to national development and North American integration? Nuestra Economía, Facultad de Economía - Universidad Autónoma de Baja California, año 2, n.8, p.39-63, mayo/ago. 1991.

GIL, J. L. Aprendizaje y construcción de capacidades tecnológicas en empresas proveedoras nacionales de la industria maquiladora de exportación. Working paper (Doctorado en Ciencias de la Administración) - Unam, 2002.

HOBDAY, M. Innovation in East Asia. The challenge to Japan. Aldershot: Edward Elgar, 1995.

East vs South Asian innovation systems: comparing OEM and TNC- led growth in electronics. In: KIM, L; NELSON, R. (Ed.). Technological learning and economic development: the experience of the Asian NIEs. Cambridge: Cambridge University Press, 1999.

HUALDE, A. Aprendizaje industrial en la frontera norte de México. [S.I.]: Colef/Plaza y Valdes Ed., 2001.

KATZ, J. Domestic technological innovations and dynamic comparative advantage: Further reflexions on a comparative case-study program. Journal of Development Studies, v.16, n.1-2, p.13-38, 1984.

KIM, L. From imitation to innovation. The dynamics of Korea's technological learning. Boston, MA: Harvard Business School Press, 1997.

LALL, S. Technological capabilities and industrialization. World Development, v.20, n.2, p.165-86, 1992.

LARA, R. A. Aprendizaje tecnológico y mercado de trabajo en las maquiladoras japonesas. Porrúa, M éxico: UAM/ Unam/M .A., 1998. 
. El nacimiento de las maquiladoras de tercera generación: el caso Delphi-Juárez. Comercio Exterior, v.50, n.9, p.771-779, 2000.

LOWE, N.; KENNEY, M. Foreign investment and the global geography of production: why the Mexican consumer electronics industry failed. World Development, v.27, n.8, p.1427-1443, 1999.

MTC. ¿Qué pasa MTC? Sep. 2000.

RADOSEVIC, S International technology transfer and catch- up in economic development. Cheltenham: Edward Elgar, 1999.

ROYAL PHILIPS ELECTRONICS. Annual report. The Netherlands, [entre 1993 e 2003]

SAMPEDRO, J. L. Aprendizaje y acumulación de capacidades tecnológicas en la IME: Thomson-Multimedia de México. Tesis (Maestría en Economía y Gestión del Cambio Tecnológico) - UAM-X, 2003.

URIÓSTEGUI, A. Del ensamble de componentes al producto final: el caso de Philips México. Tesis (Maestría en Economía y Gestión del Cambio Tecnológico) - UAM-X, 2002.

VERA-CRUZ, A. O.; GIL, J. L. Creación de redes como un mecanismo para el desarrollo de capacidades de los provedores mexicanos de la maquila: el caso de la industria del maquinado. In: LASTRES, H.; CASSIOLATO, J. (Ed.). Pequena empresa: cooperação e desenvolvimento local. Rio de Janeiro: Relume Dumará, 2003. 